Wise, M., and Spector, S.: A 5-year clinical evaluation of a therapeutic program for patients with cystic fibrosis. J. Pediatr., 65: 677 (1964).

14. Finch, P. R., Yeun, R., Schachter, H., and Moscarello, M. A.: Enzyme methods for microassay of D-mannose, D-glucose, D-galactose, and L-fucose from acid hydrolysis of glycoproteins. Anal. Biochem., 31: 296 (1969).

15. Hanover, J. A., Lennarz, W. J., and Young, J. D.: Synthesis of N- and Olinked glycopeptides in oviduct membrane preparations. J. Biol. Chem., 255: $6713(1980)$

16. Hosli, P. and Vogt, E.: Cystic fibrosis: leakage of lysosomal enzymes and of alkaline phosphatase into the extracellular space. Biochem. Biophys. Res. Commun., 79: 741 (1977).

17. Hunt, L. A. and Summers, D. F.: Glycosylation of VSV glycoprotein is similar in cystic fibrosis, heterozygous carrier, and normal human fibroblasts. J. Supramol. Struct., 7: 213 (1977).

18. Isenberg, J. N., Sahlstrom, S. J., and Sharp, H. L.: The glycoprotein-degrading proteins of peripheral leukocytes in cystic fibrosis. Am. Rev. Resp. Dis., 113: 567 (1976).

19. Kornfeld, R., Baenziger, J., and Kornfeld, S.: The structure of the glycopeptide of human G myeloma protein. J. Biol. Chem., 246: 3259 (1971).

20. Laemmli, W. G. and Favre, M.: Maturation of the head of bacteriophage T4. J. Mol. Biol., 80: 575 (1973).

21. Levy, D. E., Horner, A. A., and Solomon, A.: Immunoglobulin-sulfated polysaccharide interactions. Binding of agaropectin and heparin by human IgG protein. J. Expl. Med., 153: 883 (1981).

22. Louisot, P., Levrat, C., and Gilly, R.: A new pathogenic hypothesis for cystic fibrosis: hyperactivity of glycosyl transferases at the microsomic level. Clin. Chem. Acta, 48: 373 (1973)

23. Margolies, R.: Ph.D. Thesis, City University of New York, 1981.

24. Margolies, R. T., Gray, B., and Boat, T. F.: Identification of a major heparinprecipitable protein in human serum and its relationship to cystic fibrosis. Pediatr. Res., 16: 181 (1982).

25. McFarland, H., Holzel, A., Brenchley, P., Allen, J. D., Wallwork, E. C., Singer, B. E., and Worsley, B.: Immune complexes in cystic fibrosis. Brit. Med. J., 1: 423 (1975).

26. Morell, A. G., Gregoriades, G., Scheinberg, I. H., Hickman, J., and Ashwell, G.: The role of sialic acid in determining the survival of glycoproteins in the circulation. J. Biol. Chem., 246:1461 (1971).

27. Narasimhan, S., Wilson, J. R., Martin, E., and Schachter, H.: A structural basis for four distinct elution profiles on concanavalin A-sepharose chromatography of glycoproteins. Can. J. Biochem., 57: 83 (1979).

28. Ouchterlony, O, and Nilson, L. A.: Immunodiffusion and immunoelectrophoresis. In: D. M. Weir: Handbook of Experimental Immunology, 3rd ed., p. 19.1 (Blackwell Scientific Publication, Oxford, 1978).

29. Pearson, R. D. and Lubin, A. H.: A simple method for estimating a "heparin binding capacity" of human serum, Health Lab. Sci., 15(1): 32 (1978).

30. Pearson, R. D. and Lubin, A. H.: Increased heparin binding in cysiic fibrosis: A reflection of altered glycoprotein synthesis? Pediatr. Res., 13: 834 (1979).

31. Sarris, A. H. and Palade, G. E.: The sialoglycoproteins of murine erythrocyte ghosts. A modified periodic acid-Schiff stain procedure staining nonsubstituted and O-acetylated sialyl residues on glycopeptides. J. Biol. Chem., 254: 6724 (1979).

32. Scanlin, T. F., Voynow, J. A., Thomas, E. J., and Glick, M. C.: Glycoproteins in culture medium: A comparison from cystic fibrosis and control skin fibroblasts. Biochemistry, 21: 491 (1982).

33. Scanlin, T. F., Matacic, S. S., Pace, M., Santer, V. V., and Glick, M. C.: Abnormal distribution of alpha-L-fucosidase in cystic fibrosis: increased activity in skin fibroblasts. Biochem. Biophys. Res. Commun., 79: 869 (1977).

34. Schultze, H. E., Haupt, K., Heide, G., Moschlin, R., Schmidtberger, R., and Schwick, G.: Studies on gamma macroglobulin in human serum. $Z$. Naturforsch., 17b: 313 (1962)

35. Shapira, E. and Menendez, R.: Increased binding of Concanavalin A to alpha $2^{-}$ macroglobulin, IgM, and IgG from cystic fibrosis plasma. Biochem. Biophys. Res. Commun. 93: 1 (1980).

36. Thornburg, R. W., Day, J. F., Baynes, J. W., and Thorpe, S. R.: Carbohydrate mediated clearance of immune complexes from the circulation. A role for galactose residues in hepatic uptake of IgG-antigen complexes. J. Biol. Chem., 255: 682 (1980).

37. Boat, T. F., Cheng, P. W., Iyer, R. N., Carlson, D. M., and Polony, I.: Human respiratory tract secretions: Mucous glycoproteins of nonpurulent tracheobronchial secretions, and sputum of patients with bronchitis and cystic fibrosis. Arch. Biochem. Biophys., 177: 95 (1976).

38. Wesley, A., Forstner, J., Qureshi, R., Mantle, M., and Forstner, G.: Human intestinal mucin in cystic fibrosis. Pediatr. Res., 17: 65 (1983).

39. Frates, R. C., Kaizu, T. T., and Last, J. A.: Mucous glycoproteins secreted by respiratory epithelial tissue from cystic fibrosis patients. Pediatr. Res., 17: 30 (1983).

40. The authors would like to thank Dr. R. N. Smith for helpful suggestions concerning $\lg G$ purification and Dr. P. W. Cheng and llona Polony for help in performing some of the carbohydrate analyses.

41. Requests for reprints should be addressed to: Thomas F. Boat, University of North Carolina, 509 Burnett-Womack Bldg, 229H, Chapel Hill, North Carolina, 27514.

42. This research was supported by NIH Grant AM 08305, a Parker B. Frances Foundation Fellowship, and the Rainbow Chapter of the Cystic Fibrosis Foundation.

43. Received for publication March 11, 1983

44. Accepted for publication June 17, 1983.

\title{
Severe Combined Immunodeficiency in a Child with a Healthy Adenosine Deaminase Deficient Mother
}

\author{
FRANK C. SCHMALSTIEG, ${ }^{(26)}$ GORDON C. MILLS, HIROKO TSUDA, AND \\ ARMOND S. GOLDMAN \\ Department of Pediatrics and Human Biological Chemistry and Genetics, The University of Texas Medical \\ Branch, Galveston, Texas, USA
}

\begin{abstract}
Summary
We investigated adenosine deaminase (ADA) deficient severecombined immunodeficiency (SCID) in an 8-month-old child with ADA deficient mother. The ADA deficiency in the child was unusual in that the thymic histology was normal. In addition, the thymocytes formed E-rosettes with sheep erythrocytes and were stimulated by T-cell mitogens. ADA activity could not be detected in the child's thymocytes.
\end{abstract}

Studies on the family indicated that the father had about onehalf of the normal erythrocyte ADA activity. All the family members with detectable ADA activity appeared to have, according to starch gel electrophoresis of erythrocyte lysates, the common ADA-1 phenotype; however, rigorous identification of phenotype was not possible in this study. The mother had less than $1 \%$ of normal ADA activity in both erythrocyte and lymphocyte extracts, but her whole peripheral blood lymphocytes demonstrated about $6 \%$ of normal activity. Normal concentrations of 
ATP and small amounts of dATP were found in the mother's erythrocytes. Deoxyadenosine excretion in her urine was elevated and approximately 5-10\% of that excreted by individuals with ADA deficient SCID. These studies suggest that low amounts of ADA activity in erythrocytes and blood lymphocytes of certain individuals may be compatible with good immune function and longevity.

\section{Abbreviations}

ADA, adenosine deaminase

Con-A, concanavalin A

PHA-P, phytohemmagglutinin

SCID, severe-combined immunodeficiency

dATP, deoxy-adenosine triphosphate

ADA deficiency is associated with approximately $30-50 \%$ of the cases of autosomal recessive $\operatorname{SCID}(1,6,12)$. The clinical, metabolic, and biochemical aspects of this immunodeficiency have been investigated extensively $(7,8,10,18,19,21,24)$. Individuals with this form of SCID invariably have profound deficiencies of ADA activity in both erythrocytes and lymphocytes (12); however, there are reports of individuals with partial deficiencies of this enzyme who apparently have normal or near normal function of the immune system $(3,11,13)$. A 12-yearold boy from the !Kung tribe (25) in the Kalahari desert in Africa had $2-3 \%$ of normal ADA activity in erythrocytes and about $10-12 \%$ of normal ADA activity in blood lymphocytes (13). Similar erythrocyte and leukocyte ADA activities were reported in a black child in the United States $(3,11)$. In addition, heat lability of the U.S. child's leukocyte ADA was increased.

We recently studied a unique family pattern of ADA deficiency. The child and her mother both had ADA deficiency; but the mother was healthy and the child was immunodeficient. The studies suggest that the mother was homozygous for a low activity ADA gene whereas the infant had that gene and a silent ADA allele.

\section{CASE REPORT}

The child, a black female, was well until 2 months of age at which time she developed a purulent nasal discharge and a cough which did not respond to antibiotic therapy. She was hospitalized at 4 months of age with pneumonia and diarrhea. Although she appeared to improve initially, the pneumonia ultimately became worse. When she was referred to our hospital at 6 months of age, she had bilateral otitis media, maxillary sinusitis, and pneumonia. Physical examination revealed small tonsils, but absent peripheral lymphoid tissue. An immunologic investigation revealed a profound $\mathrm{T}$-cell deficiency (Table 1). A diagnosis of ADA deficiency was made by a study of the child's erythrocyte lysates. Because of the continued deterioration of her lung function, an open lung biopsy was performed. No fungal, bacterial, or viral organisms were detected by direct microscopy or culture. The lung tissue demonstrated chronic inflammation with few, if

Table 1. Immunologic studies ${ }^{1,2}$

\begin{tabular}{lcc}
\hline & Patient (child) & Normal \\
\hline IgG & $540 \mathrm{mg} / \mathrm{dl}$ & $325-875 \mathrm{mg} / \mathrm{dl}$ \\
IgM & $215 \mathrm{mg} / \mathrm{dl}$ & $50-200 \mathrm{mg} / \mathrm{dl}$ \\
IgA & $127 \mathrm{mg} / \mathrm{dl}$ & $15-88 \mathrm{mg} / \mathrm{dl}$ \\
Lymphocytes & $504 / \mathrm{mm}^{3}$ & $>2000 / \mathrm{mm}^{3}$ \\
E-Rosettes & $35 / \mathrm{mm}^{3}$ & $1620-4230 \mathrm{~mm}^{3}$ \\
EAC-Rosettes & $50 / \mathrm{mm}^{3}$ & $470-2590 \mathrm{~mm}^{3}$ \\
PHA stimulation & $124 \mathrm{cpm}$ & $49,912 \pm 16,839 \mathrm{cpm}$ \\
\hline
\end{tabular}

\footnotetext{
${ }^{1}$ Studies were performed when the child was 8 months of age.

${ }^{2}$ Abbreviations: EAC, erythrocyte antibody complement and PHA, phytohemagglutinin.
}

any, normal alveoli. A few cells appeared to have inclusion bodies. A thymus biopsy obtained during the procedure appeared to be normal on histologic examination (Fig. 1). Afterwards, the pneumonia became worse and she died at age 8 months of respiratory failure. In order to provide genetic counseling, all available members of the family were investigated for ADA activity in their erythrocyte lysates (Fig. 2). The mother had no detectable activity.

\section{MATERIALS AND METHODS}

Chemical and solutions. Analytical grade ion exchange resins (200/400 mesh) were obtained from Bio-Rad Laboratories (Richmond, CA). Chloroacetaldehyde was prepared from the dimethylacetal derivative as described previously (21). PHA-P and Con-A were obtained from Difco Laboratories (Detroit, MI) and were used without further modification. Starch suitable for starch gel electrophoresis was from Electrostarch Co. (Madison, WI, Lot \#392). $\left[8-{ }^{14} \mathrm{C}\right]$-Adenosine $(54.7 \mathrm{mCi} / \mathrm{mmole})$ was obtained from New England Nuclear (Boston, MA). PEI-cellulose thin layer chromatography plates were purchased from J.T. Baker Chemical Co. (Phillipsberg, NJ).

Cell isolation. Heparinized venous blood was centrifuged within $15 \mathrm{~min}$ of collection. Plasma was removed from the erythrocytes, which were suspended in a corresponding amount of $0.154 \mathrm{M} \mathrm{NaCl}$. The red cell suspension was deproteinized with cold trichloroacetic acid (21).

Lymphocytes were isolated by Ficoll-Hypaque density centrifugation (4). These cells were either disrupted by Dounce homogenization and subsequent sonication or used as whole cells. These cells were contaminated by as much as $30 \%$ monocytes.

Immunologic studies. Peripheral blood lymphocytes or thymocytes were cultured with PHA-P $(3 \mu \mathrm{g} / \mathrm{ml})$ or Con-A $(100 \mu \mathrm{g} /$ $\mathrm{ml}$ ) for 3 days (9). The extent of stimulation was determined by measuring the incorporation of $\left[{ }^{3} \mathrm{H}\right]$-thymidine by these lymphocytes. E-rosettes were formed with sheep erythrocytes and counted according to the method of Jondal et al. (14). Serum immunoglobulins were quantitated by the Mancini method using commercial plates and standards (16).

\section{ADA DETERMINATIONS}

Erythrocytes lysates. Erythrocytes lysates were prepared as described previously (21). The reaction was followed spectrophotometrically by the conversion of adenosine to inosine as described by Kalckar (15).

Mononuclear cell lysates. ADA activity in lysates of peripheral blood lymphocytes or thymocytes was measured by the conversion of $\left[8-{ }^{14} \mathrm{C}\right]$-adenosine to $\left[8-{ }^{14} \mathrm{C}\right]$-inosine and $\left[8-{ }^{14} \mathrm{C}\right]$-hypoxanthine at $37^{\circ} \mathrm{C}$. The reaction media consisted of $0.05 \mathrm{M}$ sodium phosphate buffered saline $0.154 \mathrm{M}, \mathrm{pH}$ 7.4. The adenosine concentration was $1 \times 10^{-4} \mathrm{M}$ (specific activity, $0.54 \mathrm{mCi}$ / mmole). Adenosine, inosine, and hypoxanthine were separated by one dimensional thin layer chromatography on PEI-cellulose using the solvent system ammonium hydroxide:water $(20: 80 \mathrm{v} /$ v). Spots corresponding to each of the three compounds were cut out and counted in a liquid scintillation system.

ADA activity in whole cells. ADA activity in approximately 2 $\times 10^{6} \mathrm{cell} / \mathrm{ml}$ was determined with the same assay conditions described for the leukocyte determinations. No correction was made for adenylate deaminase activity. Starch gel electrophoresis was carried out as described previously by Spencer et al. (23).

Erythrocyte nucleotides. Anion exchange chromatography of erythrocyte nucleotides and phosphate esters was accomplished using a multiple column technique (21). For determination of dATP in erythrocytes, an aliquot of a protein-free supernate of red cells was applied to a $1 \times 3 \mathrm{~cm}$ AGl-X4 anion exchange column, $\mathrm{Cl}^{-}$form. The resin was washed with $60 \mathrm{ml}$ of water to remove free purines and nucleosides. The column was then placed inside a small test tube and $8 \mathrm{ml}$ of $0.3 \mathrm{~N} \mathrm{HCl}$ was applied 

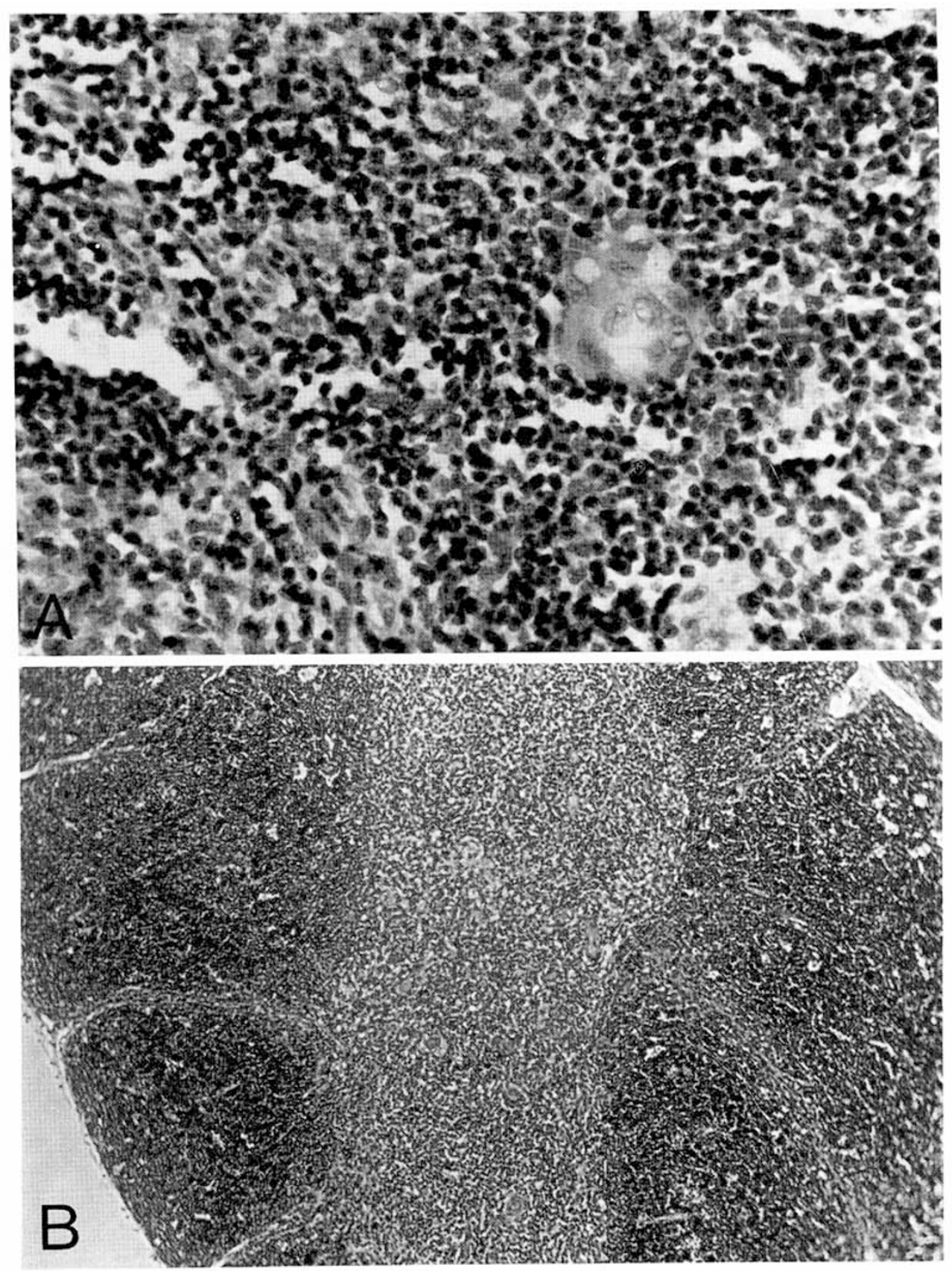

Fig. 1. Hematoxylin-eosin preparation of the AdA deficient child's thymus at 8 months of age. Cellularity and Hassal's corpuscles appeared normal $(A, \times 100$ and $B, \times 400)$.

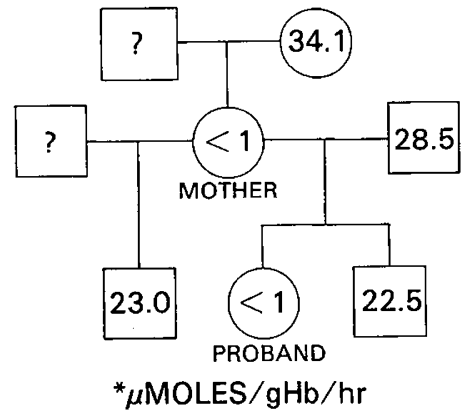

Fig. 2. Family studies of erythrocyte adenosine deaminase (normal mean, $62.5 \mu$ mole $\left.\cdot \mathrm{g} \mathrm{Hgb}^{-1} \cdot \mathrm{h}^{-1}\right)$. and allowed to drip through until the liquid level was just above the resin. The flow was stopped and the column was left at room temperature for $2 \mathrm{~h}$ to hydrolyze the purine ribose bond of deoxyribo-nucleotides. The $\mathrm{HCl}$ was then allowed to drip through the column and was followed by two 25 - $\mathrm{ml}$ water washes. The adenine in the combined $\mathrm{HCl}$ and water eluates was determined as the etheno derivative after separation on a cation exchange column, as described previously (17). Under these conditions, all of the dATP is converted to adenine with no significant adenine formation from ATP.

Adenosine, deoxyadenosine, and adenine in erythrocytes and urine. Because deoxyadenosine is unstable on cation exchange columns $\left(\mathrm{H}^{+}\right.$form), initial separation of urine and protein-free erythrocyte lysates was accomplished on short anion exchange columns $\left(1 \times 5 \mathrm{~cm}, \mathrm{AGl}-\mathrm{X} 4, \mathrm{Cl}^{-}\right.$form $)$, at $\mathrm{pH} 10$. Under these 
conditions, deoxyadenosine was stable and eluted from the column along with adenosine in the column wash. Adenine, which was retained, was eluted with $0.077 \mathrm{M}$ sodium acetate, $\mathrm{pH}$ 5.2. The original column wash containing adenosine and deoxyadenosine was added to a cation exchange column $(0.5 \times 20 \mathrm{~cm}$ AG50-X4, $\mathrm{H}^{+}$form). Elution was accomplished sequentially with $0.77 \mathrm{M}$ sodium acetate, $\mathrm{pH} 4.8$ and $0.077 \mathrm{M}$ sodium acetate $\mathrm{pH}$ 5.2 , as previously described (21). Under these conditions, deoxyadenosine is converted to adenine, whereas adenosine remains unchanged. Aliquots of the separated compounds were added to $0.5 \mathrm{ml}$ of $0.2 \mathrm{M}$ chloroacetaldehyde and heated $40 \mathrm{~min}$ at $80^{\circ} \mathrm{C}$ to form ethenoadenine and ethenoadenosine. These fluorescent derivatives were measured quantitatively by their fluorescence at $425 \mathrm{~nm}$ after excitation at $280 \mathrm{~nm}$.

Determination of uric acid and creatinine. Uric acid was determined by UV spectrophotometry after anion exchange separation (22). Creatinine was determined in the cation exchange $\mathrm{HCl}$ elution profile by its absorbance at $230 \mathrm{~nm}$ (17).

Table 2. Thymic lymphocytes ${ }^{1}$

\begin{tabular}{lcc}
\hline & Patient (child) & Normal \\
\hline E-Rosettes & $98 \%$ & $>90 \%$ \\
EAC-Rosettes & $>2 \%$ & \\
PHA stimulation & $1027 \mathrm{cpm}$ & $474 \mathrm{cpm}$ \\
Con-A stimulation & $985 \mathrm{cpm}$ & $2597 \mathrm{cpm}$ \\
\hline
\end{tabular}

' Abbreviations: EAC, erythrocyte antibody complement; PHA, phytohemagglutinin: and Con-A, concanavalin A.

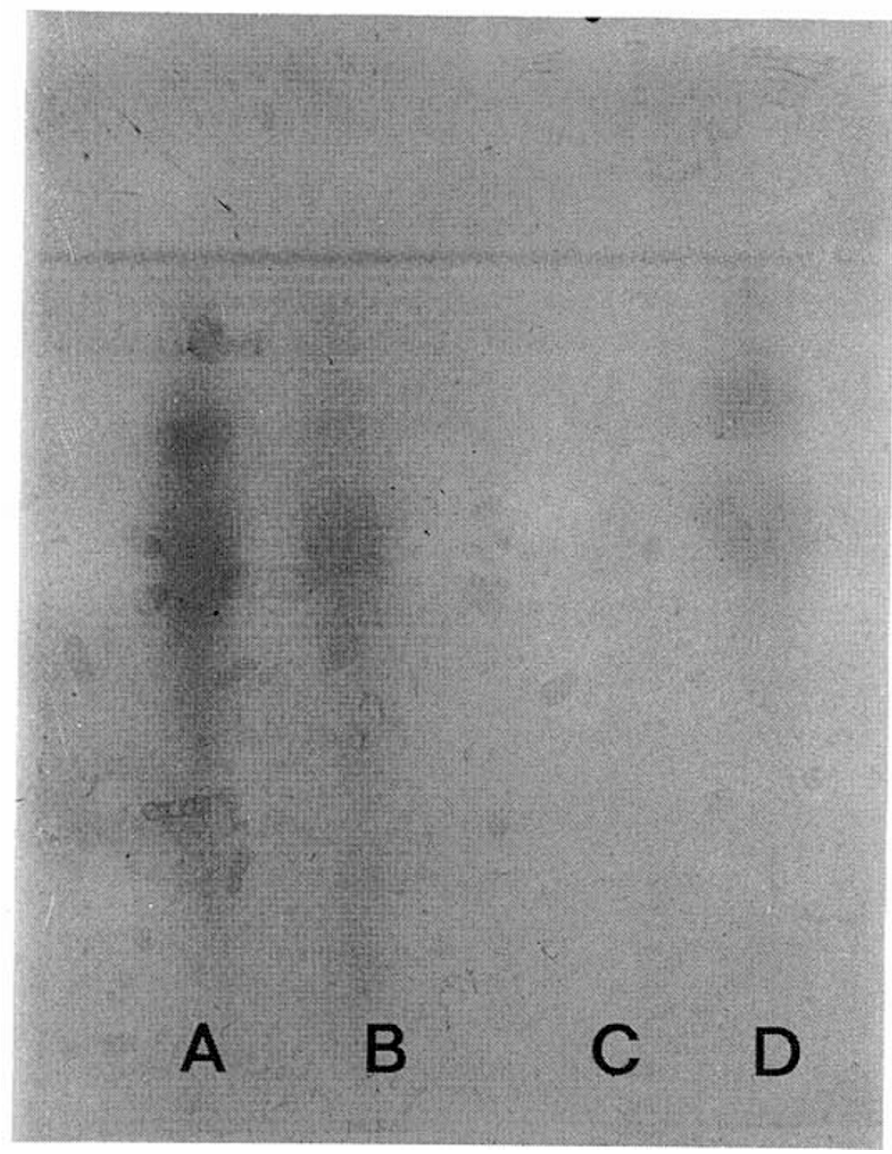

Fig. 3. Starch gel electrophoresis of erythrocyte adenosine deaminase (ADA). $(A)$ Known ADA-1-phenotype; $(B)$ male sibling; $(C)$ mother; and $(D)$ father. Because erythrocyte lysates were electrophoresed only in the absence of mercaptoethanol, definitive identification of ADA phenotypes is not possible from this study.

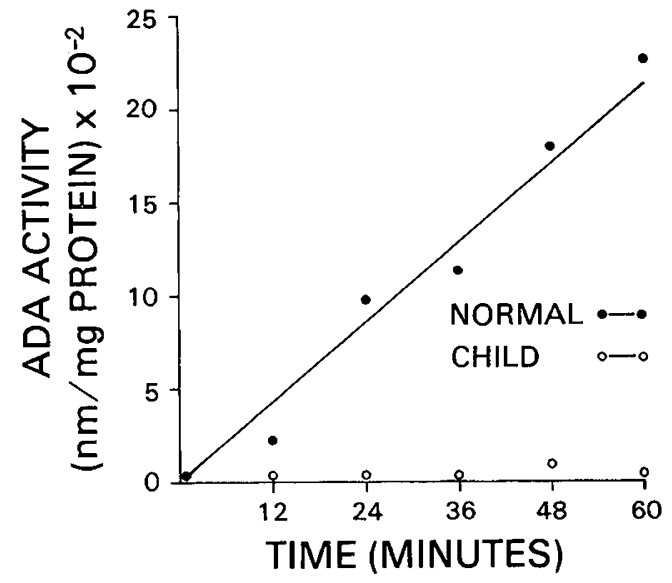

Fig. 4. Adenosine deaminase (ADA) activity in child's thymocytes. The control is from a thymic biopsy taken during cardiac surgery the same day as the patient's thymic biopsy. Manipulation of the two specimens was identical. ADA activity was determined from the conversion of $\left[8-{ }^{14} \mathrm{C}\right]$-adenosine to $\left[8-{ }^{14} \mathrm{C}\right]$-inosine and $\left[8-{ }^{14} \mathrm{C}\right]$-hypoxanthine (sensitivity of this assay was approximately $1.2 \mathrm{nmole} \cdot \mathrm{mg}$ protein ${ }^{-1}$. $\left.\min ^{-1}\right)$.

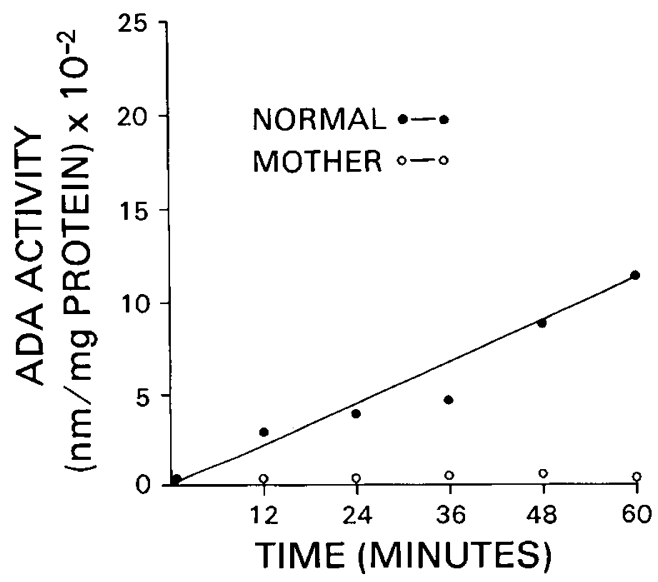

Fig. 5. Adenosine deaminase (ADA) activity in mother's peripheral blood mononuclear cell lysates. ADA activity was determined from the conversion of $\left[8-{ }^{14} \mathrm{C}\right]$-adenosine to $\left[8-{ }^{14} \mathrm{C}\right]$-inosine and $\left[8-{ }^{14} \mathrm{C}\right]$-hypoxanthine (sensitivity of this assay was approximately $1.8 \mathrm{nmole} \cdot \mathrm{mg}$ pro$\left.\operatorname{tein}^{-1} \cdot \min ^{-1}\right)$.

\section{RESULTS}

Immunologic studies. Absolute numbers of blood lymphocytes, E-rosetting cells, and erythrocyte antibody complement rosetting cells were all decreased significantly as was stimulation of peripheral blood lymphocytes by PHA-P as measured by $\left[{ }^{3} \mathrm{H}\right]$ -thymidine uptake (Table 1). In contrast, immunoglobulins were quantitatively normal. In addition, the patients' thymocytes demonstrated a normal number of E-rosetting cells and incorporated $\left[{ }^{3} \mathrm{H}\right]$-thymidine to a similar degree as the normal when cultured with Con-A or PHA-P (Table 2). Histologic sections of the thymus demonstrated normal architecture with numerous Hassal's corpuscles. (Fig. 1).

Erythrocyte ADA activity. Both the mother and child had less than $1 \%$ of normal ADA activity in their erythrocyte lysates. The father, a maternal grandmother, and two siblings of the child each had approximately one-half of normal activity (normal mean, $\mu$ mole $\cdot \mathrm{g} \mathrm{Hgb}^{-1} \cdot \mathrm{h}^{-1}$ (Fig. 2). Starch gel electrophoresis of erythrocyte lysates from the same members of this family demonstrated either no activity (mother) or an apparent ADA-1 phenotype (Fig. 3). 
$A D A$ activity in mononuclear cell lysates. Using the $\left[8-{ }^{14} \mathrm{C}\right]-$ adenosine ADA assay, no ADA activity as measured by the appearance of labeled inosine or hypoxanthine could be detected in lysates of the patient's thymocytes (Fig. 4). Normal thymocytes, recovered from a patient during cardiac surgery and treated exactly as the patient's thymic biopsy, showed an ADA activity of $40 \mathrm{nmole} \cdot \mathrm{mg}$ protein ${ }^{-1} \cdot \mathrm{min}^{-1}$. This value is approximately $20 \%$ of that reported in the literature $(2,5)$. The reason for this disparity is unknown; however, it is clear that the patient had less than $1 \%$ of normal activity in her thymocyte lysates.

Unexpectedly, the mother had no detectable ADA activity in her mononuclear cell lysates from peripheral blood (Fig. 5). About $6 \%$ of normal activity could be detected in the mother's mononuclear cells when they were assayed as whole cells (Fig. 6). No correction was made in this assay for adenylate deaminase activity.

Erythrocyte and urinary purines. The mother's adenine, adenosine, erythrocyte ATP, ADP, and AMP were within normal limits (Table 3). Both adenine and deoxyadenosine were elevated in the mother's urine (Table 4). Small but detectable amounts of dATP (35 $\mu$ mole/liter erythrocytes) were found.

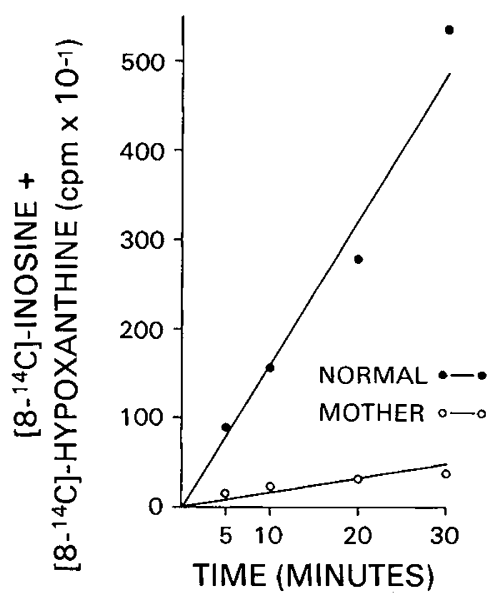

Fig. 6. ADA activity in mother's whole peripheral blood mononuclear cells. ADA activity was determined from the conversion $\left[8-{ }^{14} \mathrm{C}\right]$ adenosine to $\left[8-{ }^{14} \mathrm{C}\right]$-inosine and $\left[8-{ }^{14} \mathrm{C}\right]$-hypoxanthine. No correction was made for adenylate deaminase activity.

Table 3. Erythrocyte purines of the mother ${ }^{1}$

\begin{tabular}{lcc}
\hline \multicolumn{1}{c}{ Compounds } & Mother & Controls \\
\hline AMP & 24 & $18.6 \pm 5.3$ \\
ADP & 165 & $170 \pm 25$ \\
ATP & 1490 & $1400 \pm 145$ \\
dATP & 35 & \\
Adenosine & $<1.6$ & $1.1 \pm 0.4$ \\
Adenine & 8.2 & $5.3 \pm 3.2$ \\
Deoxyadenosine & $<1.4$ & \\
\hline
\end{tabular}

${ }^{1}$ Concentrations of compounds are expressed as $\mu$ mole/liter of erythrocytes. The lower limits of detection for dATP was approximately 5 $\mu$ mole/liter of erythrocytes.

Table 4. Urinary purine compounds ${ }^{1}$ in the mother

\begin{tabular}{lclc}
\hline \multicolumn{1}{c}{ Compound } & $\begin{array}{c}\text { Urine } \\
(\mathrm{nmole} / \mathrm{ml})\end{array}$ & \multicolumn{3}{c}{ Creatinine $($ nmole $/ \mu$ mole) } \\
\hline Adenine & 163 & 1.95 & $(0.74 \pm 0.22)$ \\
Adenosine & 1.0 & 0.12 & $(0.64 \pm 0.32)$ \\
Deoxyadenosine & 11.8 & 1.41 & $(0.20 \pm 0.17)$ \\
\hline
\end{tabular}

${ }^{1}$ Normal adult values (mean \pm S.D.) are shown in parentheses. Similar studies in the child were not performed.

\section{DISCUSSION}

This is the first report of a healthy ADA deficient mother producing an ADA deficient infant with SCID. The low numbers and function of peripheral blood T-lymphocytes, and the clinical features of the child were consistent with other reported cases of ADA deficient SCID. The child, however, was unusual in that the thymus was histologically normal (Fig. 1). Furthermore, the thymocytes retained some functional capabilities because they were able to form E-rosettes and could be stimulated by Con-A and PHA-P. Because of the atypical features of this ADA deficiency, the erythrocyte and lymphocyte levels of ADA activity were measured in the parents and other available family members. The father displayed an intermediate level of erythrocyte ADA activity typical of reported carriers of this enzyme defect. In contrast to the usual carriers of ADA deficiency, the maternal erythrocytes lacked ADA activity; thus, it appears that the child was the product of parents with two genetic types of ADA abnormalities, the more unusual type of which presented in an asymptomatic, apparently immunocompetent individual (mother).

Erythrocyte ADA deficiency without immunodeficiency has been reported previously $(3,11,13)$. The first case of ADA deficiency without immunodeficiency was found in a !Kung boy of South West Africa (13). The healthy child had 2-3\% of normal enzyme activity in erythrocytes and $10-12 \%$ in lymphocytes. In this country, a black child with normal immune functions has been described with deficiencies of ADA in erythrocyte and mononuclear cell lysates and an abnormal heat sensitivity of $\operatorname{ADA}(3,11)$

The mother of the child in the present report is at least quantitatively different from previously reported healthy ADA deficient individuals in that mononuclear cell lysates and whole mononuclear cells contain less ADA activity. Despite the greatly decreased activity of ADA in erythrocytes and mononuclear cells, only small amounts of dATP were detected (Table 3). Other abnormalities in erythrocyte nucleotides and purines, such as the presence of increased concentrations of ATP or adenine reported for patients with ADA deficient SCID, were not discovered in her cells. Examination of the mother's urine revealed an increased excretion of deoxyadenosine and adenine. The excretion of deoxyadenosine (Table 4) was only $5-10 \%$ of the amount produced by another ADA deficient patient we have studied (20). The amount of deoxyadenosine excreted by the mother is probably slightly larger than that described for the previously reported child with abnormally heat sensitive $\operatorname{ADA}(3,11)$. We conclude that some cell line present in this woman must have appreciable ADA activity, and that most deoxyadenosine produced endogenously was metabolized rather than excreted.

We are unable to answer the following important questions about the ADA deficiency in this family. (1) Was the mother homozygous or heterozygous for an altered ADA gene? (2) Did the ADA deficiency represent an abnormal enzyme or was it a normal enzyme present in low concentrations? Starch gel electrophoresis of erythrocyte lysates either demonstrated no activity (mother and patient) or possibly the common ADA-1 phenotype (father and two healthy siblings). Unfortunately, enzyme studies were curtailed because the family refused further study.

Although more definitive studies would have been very helpful, we postulate that the ADA deficiencies in this family were due to two discrete genetic abnormalities: a null gene from the father and a novel, low activity gene from the mother. Because of the intermediate enzyme activity in the father's erythrocytes, the profound deficiency of ADA in the mother's cells, and the relatively normal features of the thymus of the affected child, we felt that the father was heterozygous for the null gene, the mother was homozygous for the low activity gene, and the affected child possessed both the common null gene and the low activity gene. Although there may be alternate explanations, the clinical, immunologic, and enzymatic data best supported that hypothesis. If this hypothesis is correct, there must be a distinct threshold of 
ADA activity necessary for normal immune function. Finally, although the question of subtle immune dysfunction in individuals with low activity ADA enzymes is not answered by these studies, the apparent good health of the mother suggests that the possible immunodeficiencies are not severe.

\section{REFERENCES AND NOTES}

I. Ackert, C., Pluss, H. J., and Hitzig, W. H.: Hereditary severe combined immuno-deficiency and adenosine deaminase deficiency. Pediatr. Res., 10: 67 (1976).

2. Adams, A., and Harkness, R. A.: Adenosine deaminase activity in thymus and other human tissues. Clin. Exp. Immunol., 26: 647 (1976).

3. Borkowsky, W., Gershon, A. A., Shenkman, L., and Hirschhorn, R.: Adenosine deaminase deficiency without immunodeficiency. Clinical and Metabolic Studies. Pediatr. Res., 14:885 (1980).

4. Bøyum, A.: Isolation of mononuclear cells and granulocytes from human blood. Isolation of mononuclear cells by one centrifugation, and of granulocytes by combined centrifugation and sedimentation at lg. Scand. J. Clin. Lab. Invest., 19 (Supp. 97): 77 (1968).

5. Carson, D. A., Kaye, J., and Seegmiller, J. E.: Lymphospecific toxicity in adenosine deaminase deficiency and purine nucleoside phosphorylase deficiency: Possible role of nucleoside kinases. Proc. Natl. Acad. Sci., U.S.A. 74: 5677 (1977).

6. Cohen, F., In: Combined immunodeficiency disease and adenosine deaminase deficiency: A molecular defect Eds: H. J. Mevwissen, R. J., Pickering, B., Pollara, B., and I. H. Porter pp. 245-246 (Academic Press, New York, 1975).

7. Coleman, M. S., Donofrio, J., Hutton, J. J., Hahn, L., Daoud, A., Lampkin, B., and Dyminski, $J$.: Identification and quantitation of adenine nucleotides in erythrocytes of a patient with adenosine deaminase deficiency and severe combined immunodeficiency. J. Biol. Chem., 253: 1619 (1978).

8. Giblett, E. R., Anderson, J. E., Cohen, F., Pollara, B., and Mevwissen, H. J.: Adenosine deaminase deficiency in two patients with severely impaired cellular immunity Lancet, 2: 1067 (1972)

9. Glinski, W., Gershwin, E. E., Budman, D. R., and Steinberg, A. D.: Study of lymphocyte subpopulations in normal humans and patients with systemic lupus erythematosis by fractionation of peripheral blood lymphocytes on a discontinuous Ficoll gradient. Clin. Exp. Immunol., 26: 228 (1976).

10. Hershfield, M. S., Kredich, N. M., Ownby, D. R., Ownby, H., and Buckley, R.: In-vivo inactivation of erythrocyte 5-adenosylhomocysteine hydrolase by 2-deoxyadenosine in adenosine deaminase-deficient patients. J. Clin. Invest., 63: 807 (1979).

11. Hirschhorn, R., Roegner, V., Jenkins, T., Seaman, C., Piomelli, S., and Borkowsky, W.: Erythrocyte adenosine deaminase deficiency without immunodeficiency: evidence for an unstable mutant enzyme. J. Clin. Invest.,
64: $1130(1979)$

12. Hirschhorn, R., Vawter, G. F., Kirkpatrick, J. A and Rosen, F. Adenosine deaminase deficiency: frequency and comparative pathology in autosomally recessive severe combined immunodeficiency. Clin. Immunol. Immunopathol., 14: 107 (1979).

13. Jenkins, T Rabson, A. R Nurse, G. T Lane, A. B and Hopkinson, D. A : Deficiency of adenosine deaminase not associated with severe combined immunodeficiency. J. Pediatr., 89: 732 (1976).

14. Jondal, J., Wigzell, H., and Aiuti, F.: Human lymphocyte subpopulations: Classification according to surface markers and/or functional characteristics. Transplant. Rev., 16: 163 (1973).

15. Kalckar, H. M.: Differential spectrophotometry of purine compounds by means of specific enzymes. III. studies of the enzymes of purine metabolism. J. Biol. Chem., 167: 461 (1947).

16. Mancini, G., Carbonara, A. O., and Heremans, J. F.: Immunochemical quantitation of antigens by single radial immunodiffusion. Immunochemistry, 2: 235 (1965).

17. Mills, G. C., Goldblum, R. M., Newkirk, K. E., and Schmalstieg, F. C.: Urinary excretion of purines, purine nucleosides, and pseudourine in adenosine deaminase deficiency. Biochem. Med., 20:180 (1978).

18. Mills, G. C., Schmalstieg, F. C., Trimmer, K. B., Goldman, A. S., and Goldblum, R. M.: Purine metabolism in adenosine-deaminase deficiency. Proc. Natl. Acad. Sci. USA, 73: 2867 (1976).

19. Polmar, S. H., Stern, R. C., Schwartz, A. L., Wetzler, E. M., Chase, P. A., and Hirschhorn, R.: Enzyme replacement therapy for adenosine deaminase deficiency and severe combined immunodeficiency. N. Engl. J. Med., 295. 1337 (1976).

20. Schmalstieg, F. C., Mills, G. C., Nelson, J. A., May, L. T., Goldman, A S and Goldblum, R. M.: Limited effects of erythrocyte and plasma infusions in adenosine deaminase deficiency. J. Pediatr., 93: 597 (1978).

21. Schmalstieg, F. C., Nelson, J. A., Mills, G. C., Monahan, T. M., Goldman, A S., and Goldblum, R. M.: Increased purine nucleotides in adenosine deaminase deficient lymphocytes. J. Pediatr., 91: 48 (1977).

22. Shapiro, B., Seligson, D., and Jessar, R.: Measurement of uric acid in biologic fluids using an ion-exchange separation. Clin. Chem., 3: 169 (1977).

23. Spencer, N., Hopkinson, D. A., and Harris, H.: Adenosine deaminase polymorphism in man. Ann. Human Genet. Lond., 32: 9 (1968).

24. Wolberg, G., Zimmerman, T. P., Hiemstra, K., Winston, M., and Chu, L. C. Adenosine inhibition of lymphocyte-mediated cytolysis: possible role of cyclic monophosphate. Science, 187: 957 (1975).

25. The language employed by the !Kung people utilizes "clicks" as well as words. The exclamation point serves to indicate a click.

26. Requests for reprints should be addressed to: Dr. Frank C. Schmalstieg, Department of Pediatrics, The University of Texas Medical Branch, Child Health Center, C236, Galveston, Texas 77550.

27. Received for publication February 16, 1983.

28. Accepted for publication July $19,1983$. 